\title{
Study of the Effect of Rocket Fuel on Plant Communities Growing at Sites of Launch Vehicles Separating Parts Fall
}

\author{
Anuar Bulatovic Atygayev ${ }^{1 *}$, Mukanova Gulzhanat Amangeldykyzy', \\ Bazarbayeva Tursynkul Amankeldievna', Natalia Vladimirovna Kurbatova', \\ Zubova Olga Aleksandrovna', Svetlana Yerekeyeva²
}

\author{
1 Al-Farabi Kazakh National University, 71 al-Farabi Ave., Almaty, 050040, Kazakhstan \\ 2 Kazakh National Agrarian Research University, 8 Abay Ave., Almaty, 050010, Kazakhstan \\ * Corresponding author's e-mail: killjeden92@gmail.com
}

\begin{abstract}
The article presents the results of a study of synthesis and accumulation of heptyl in the plants growing on the soil contaminated with rocket fuel. The study was carried out under laboratory conditions of al-Farabi Kazakh National University. The results of the experiments confirmed that certain concentrations of a rocket fuel-heptyl (unsymmetrical dimethylhydrazine, UDMH) are not toxic for the crested wheatgrass, Agropyron pectiniforme Roem.et Schult., Kentucky bluegrass, Poa pratensis L., and tarragon, Artemisia terrae-albae Krasch., although they can cause anatomical and morphological changes in the roots and leaves of the plants grown on the soil contaminated with UDMH. The changes in the morphological structure of plants under the influence of UDMH (in particular, in the outer tissue that protects the plant organs from drying out, temperature effects, mechanical damage and other adverse factors) can lead to an imbalance in water metabolism and gas exchange, a deterioration in the absorption and release of water, and the cessation of intake from the soil of both beneficial and harmful substances.
\end{abstract}

Keywords: unsymmetrical dimethylhydrazine, nitrosodimethylamine, rocket fuel, soil contamination, effect on plants, plant pollution.

\section{INTRODUCTION}

Since 1991, the studies of the effects of chemical pollution on the environment have been carried out in the areas of the launch vehicles separating parts fall in Central Kazakhstan, in some parts of the Tomsk, Omsk, and Novosibirsk regions of the Russian Federation, as well as in the Republics of Altai, Tuva, and Khakassia. The assessment of the ecological state of those areas was based on the analysis of accumulation and migration of unsymmetrical dimethylhydrazine (UDMH) in landscape systems [Ekologicheskaya bezopasnost..., 2011].

Highly toxic UDMH is used as the main component of rocket fuel in medium and heavy classes of launch vehicles. UDMH is a first hazard class compound with carcinogenic and mutagenic properties. When released to the environment,
UDMH transforms into a wide range of products including N-nitrosodimethylamine (NDMA), tetramethyltetrazene, hydrazones, triazoles, pyrazoles, tetrazoles, dimethylformamide, dimethylaminoacetonitrile, 1-formyl-2, and 2-dimethylhydrazine. While the toxicity of a few of the UDMH metabolites is well known, the majority of the compounds have not been studied in detail, due to the high cost of such studies. Most of the UDMH metabolites are toxic to living organisms, which necessitates monitoring their concentrations in the environment [Carlsen et al., 2009; Kolumbayeva et al., 2014; Kenessov et al., 2012; Carlsen et al., 2009; Carlsen et al., 2008].

In 1991-2015, Russian and Kazakh researchers, among them A.P. Vorozheikin, N.S. Kasimov, T.V. Koroleva, I.O. Baitulin, N.P. Ogar and A.M. Nurusheva, established that wild members of the Asteraceae, Chenopodioideae and Poaceae 
had a good ability to synthesize and accumulate UDMH and NDMA, due to the biogeochemical adaptation to the steppe and semi-desert environment of Central Kazakhstan. Small doses of heptyl can be used by plants as an additional source of nitrogen and carbon. However, large concentrations can cause morphological and anatomical changes, as well as chromosomal disorders [Kondratiev et al., 2015; Ushakova et al., 2004; Puzanov et al., 2007; Baitulin and Ogar, 2006; Nurusheva, 2006].

\section{MATERIALS AND METHODS}

On May 20th, 2019, the samples of plant raw material (roots, stems and leaves) were taken for the subsequent anatomical and morphological studies of plants grown in heptyl contaminated soil under laboratory conditions.

Microscopic studies were conducted using the plant material which was fixed in a mixture of alcohol, glycerine and water in a 1:1:1 ratio. In the manufacturing and description of the preparations, the methods generally accepted in plant anatomy were used [Prozina, 1960; Barykina et al., 2004].

When characterizing the morphological and anatomical structure of stems and roots, the following features are of particular importance: on a cross-section, at a small magnification $(\times 10)$, it is necessary to distinguish the primary cortex, most often occupying a large part of the root section, and the relatively narrow central cylinder. Their general outline, shape and structure of cells, as well as the distribution of the xylem and phloem should be described.

The root cross sections were made every 2-3 $\mathrm{cm}$ along the entire length of the roots in their basal part. For the study, plants of a certain age were taken, but the main attention was paid to middle-aged generative plants, which provide the bulk of the raw material for the study of species.

The anatomical preparations were made using a microtome with an OL-ZSO freezing device (Inmedprom, Russia). The thickness of the anatomical sections was 10-15 microns. For the quantitative analysis, morphometric indicators were measured using an MOV-1-15 eyepiece micrometer (with a lens of $\times 10$, magnification of $\times 40,10$, and 7). Microphotographs of anatomical sections were taken on an MC 300 microscope (Micros, Austria) with a CAM V400 / 1.3M video camera (jProbe, Japan).
The description of external characters was made in accordance with the requirements of the GF XI [State Pharmacopoeia..., 1987; State Pharmacopoeia..., 1990].

\section{RESULTS AND DISCUSSION}

\section{Results of the anatomical study}

In order to study the anatomical structure of the vegetative organs, the plants grown on soil contaminated with UD in a concentration equivalent to $39.4 \mathrm{mg} / \mathrm{kg}$ and a control sample grown on clean soil were taken.

\section{Anatomical structure of a bluegrass root}

On the outside, the bluegrass root was covered with the epiblema with numerous root hairs. Next, the exoderm which was followed by 1-2 layers of cells of the primary cortex, a single layer of cells of the endoderm, and the pericycle. The central cylinder was represented by elements of the primary phloem and primary xylem. In the plants grown on contaminated soil, a decrease in the size of the primary cortex was observed; the diameter of the central cylinder was reduced. All measured features of the anatomical structure were magnified (Fig. 1, Table 1).

\section{Anatomical structure of the bluegrass stalk}

In the structure of the stem, the following tissues were present: the epidermis, green assimilation parenchyma (chlorenchyma), colourless areas of the parenchyma and vascular-fibrous beams. The walls of the epidermis, which were represented by a single layer of cells, had a mesh structure, in some areas there was a thickening. The pericyclic sclerenchyma, which consisted of cells with narrow lumens and thickened walls, was adjacent to the epidermis. Assimilating tissue consisted of thin-walled parenchymal cells with chloroplasts. To the centre, there was the colourless part of the parenchyma, the cells of which were round-oval in shape and quite large in size. There were conductive beams in the walls of the stalk. The beams passing in the mechanical tissue, medium and very small in size, were located at a distance from each other. All conductive beams were closed, collateral. The beams included the elements of the xylem and phloem. The xylem was represented by 3-5 vessels, among them 1-3 with narrow lumens, constituting a short radial chain. The 
phloem had the form of a mesh, the large cells of which corresponded to the cross section of the sieve tubes. The number of beams in a stalk varied. There were fewer beams in the sclerenchyma than in the inner part of the stem. A comparative analysis of the internal structure of the stems showed an increase in the thickness of the primary cortex, sclerenchyma lining, and covering tissue in the plants grown on contaminated soil. The size of the cross-sections of conductive beams, as well as of xylem elements, remained virtually unchanged (Table 1, Fig. 2).

\section{Anatomical structure of the bluegrass leaf blade}

The leaf blade was slightly folded. The stomata were located on the upper surface of the leaf blade, in the grooves between the protrusions. The epidermis consisted of functionally different types of cells: short covering, passage (motor cells), and trichoblasts. The spongy mesophyll was homogeneous; it consisted of round cells, in some cases folded. The arrangement of the mesophyll cells was of the festucoid type. The conductive beams were collateral, the phloem and xylem were located side by side. The conductive beams were surrounded by a sclerenchyma lining (Fig. 3). The thickness of the sclerenchyma lining and the area of the conductive beams were somewhat reduced in the plants grown on the soil contaminated with UDMH. The sclerenchyma, in the form of single sections, was located at the edges of the leaf blade. In the plants from the contaminated soil, almost all parameters were reduced (Table 1).

\section{Control}

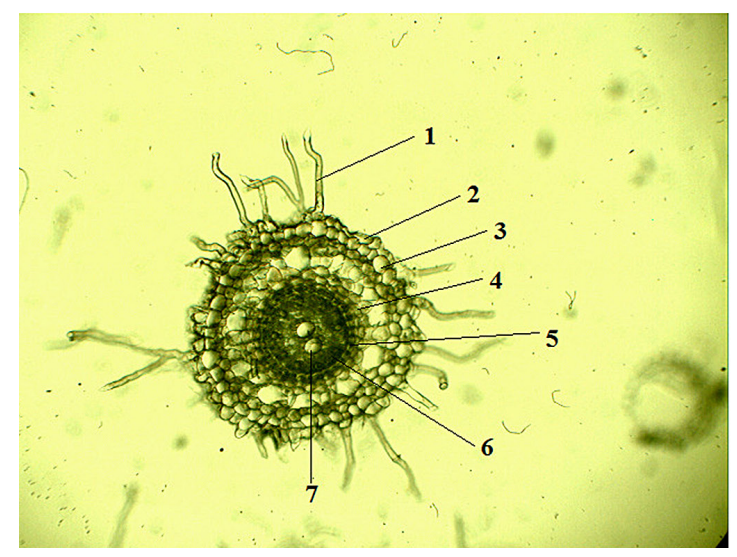

\section{Sample from contaminated soil}

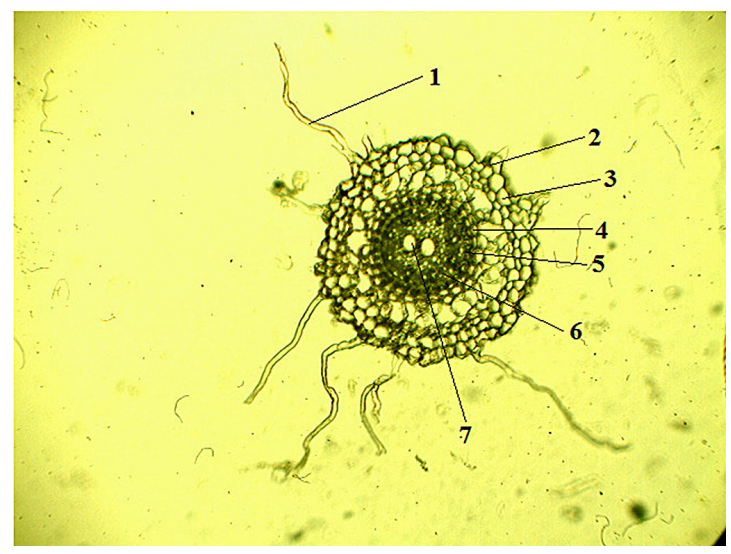

Figure 1. Anatomical structure of the bluegrass root (1 - root hairs, 2 - hairy layer (epiblema), 3 - exoderm, 4 - endoderm, 5 - pericycle, 6 - primary phloem, 7 - primary xylem)

\section{Control}

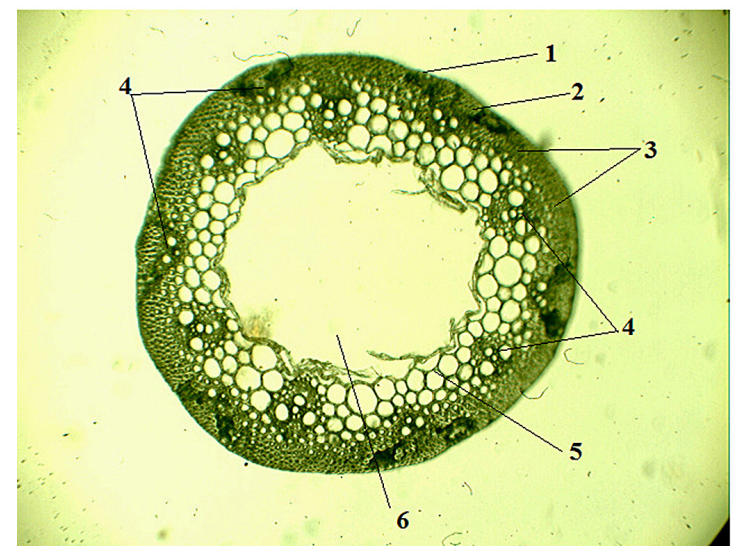

Sample from contaminated soil

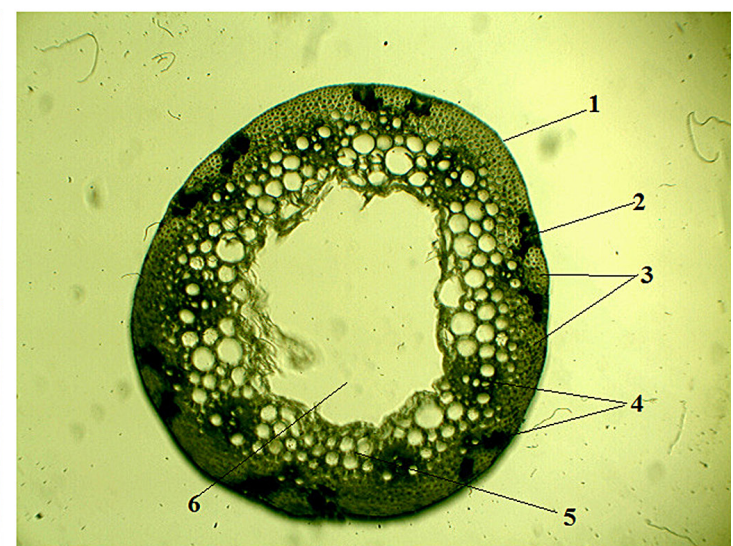

Figure 2. Anatomical structure of the bluegrass stalk (1 - epidermis, 2 - chlorenchyma or cortical parenchyma, 3 - pericyclic sclerenchyma, 4 - closed collateral bundle (phloem, xylem, lining sclerenchyma), 5 - main axial cylinder parenchyma, 6 - stalk cavity) 


\section{Control}

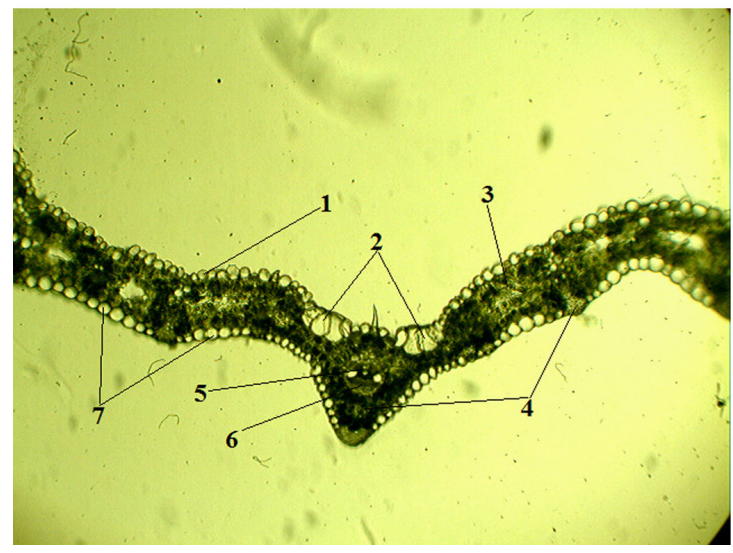

Sample from contaminated soil

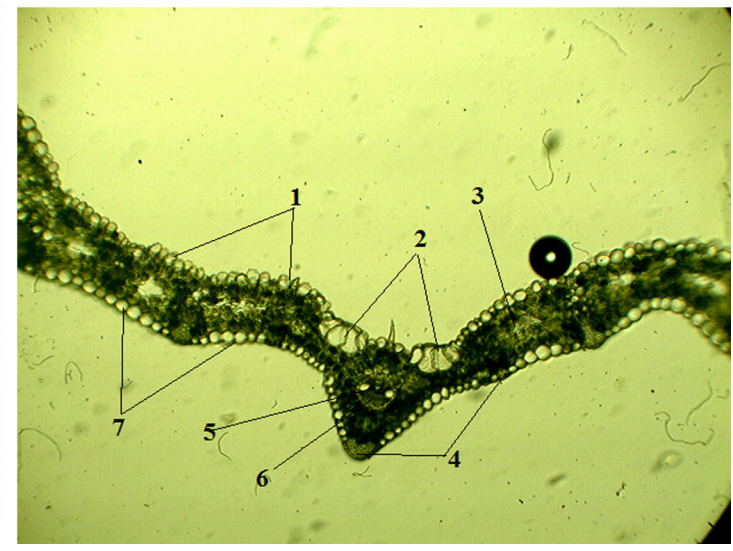

Figure 3. Anatomical structure of the bluegrass leaf blade ( 1 - upper epidermis, 2 - conductive (motor) cells, 3 - spongy mesophyll, 4 - sclerenchyma, 5 - conductive beam, 6 - lining of the beam, 7 - lower epidermis)

\section{Control}

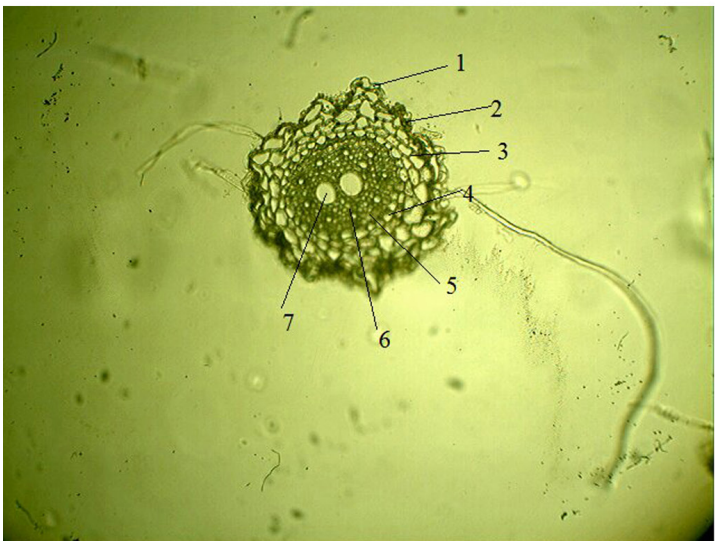

Sample from contaminated soil

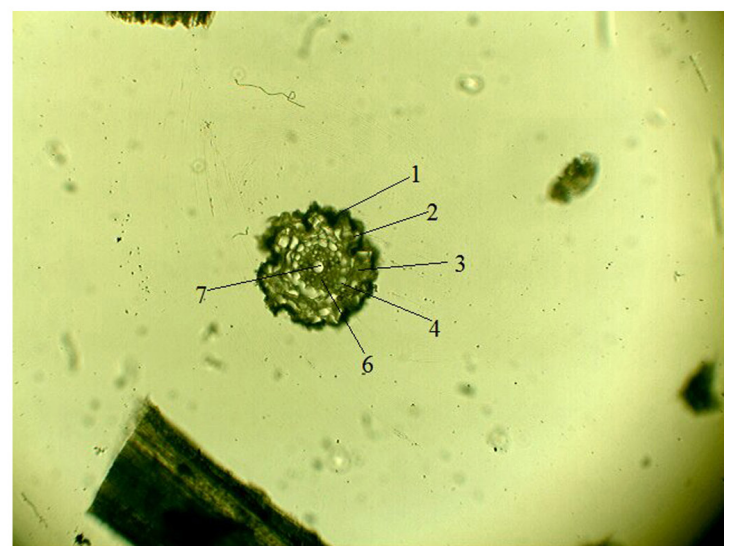

Figure 4. Anatomical structure of the wheatgrass root ( 1 - the hairy layer (epiblema), 2 - exoderm, 3 - cells of the parenchyma of the primary cortex, 4 - endoderm, 5 - pericyclic, 6 - primary phloem, 7 - primary xylem)

\section{Anatomical structure of a wheatgrass root}

The wheatgrass root was covered with the epiblem, followed by an exoderm layer. Next, there were two layers of cells of the primary cortex, followed by a single layer of the endoderm cells, and the pericycle. The central cylinder was represented by the elements of the primary phloem and primary xylem. In the plants grown on the heptyl contaminated soil, decreases in the size of the primary cortex and the diameter of the central cylinder were observed. All measured features of the anatomical structure were magnified (Fig. 4, Table 2).

\section{The anatomical structure of the wheatgrass leaf blade}

The figure shows the xerophytic type of structure of the leafblade, the upper and lower epidermis of the leaf are marked, and there is no differentiation into spongy and columnar mesophylls, because only the spongy mesophyll is present. The main conductive beam (of a larger diameter) lies in the centre of the vein, and small conductive beams are located on the periphery of the leaf. The beams have a sclerenchimal lining. Significant changes were observed in the internal structure of the leaf blades. In the plants grown on the contaminated soil, the thickness of the leaf blade, the area of the cross-section of the conductive beams and xylem vessels were reduced (Fig. 5, Table 2).

\section{The anatomical structure of the roots of wormwood (Artemisia terrae-albae)}

In the root, secondary changes in growth were observed. Outside, the root was covered withthe periderm (secondary protective tissue), which 


\section{Control}

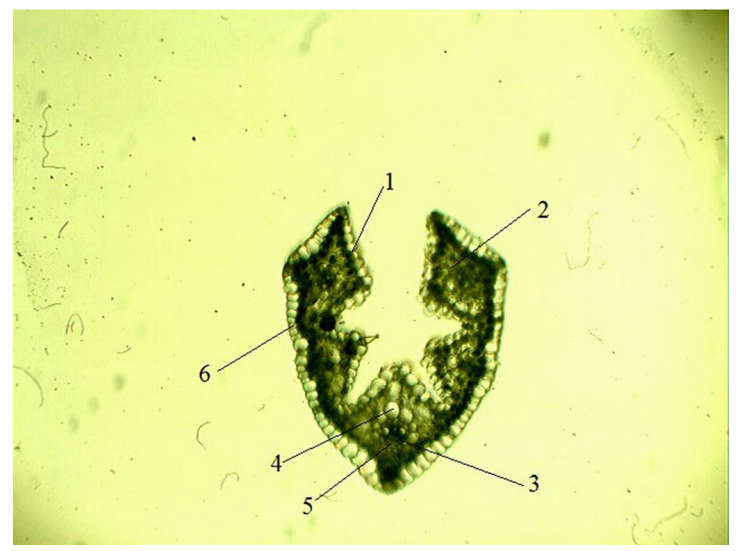

Sample from contaminated soil

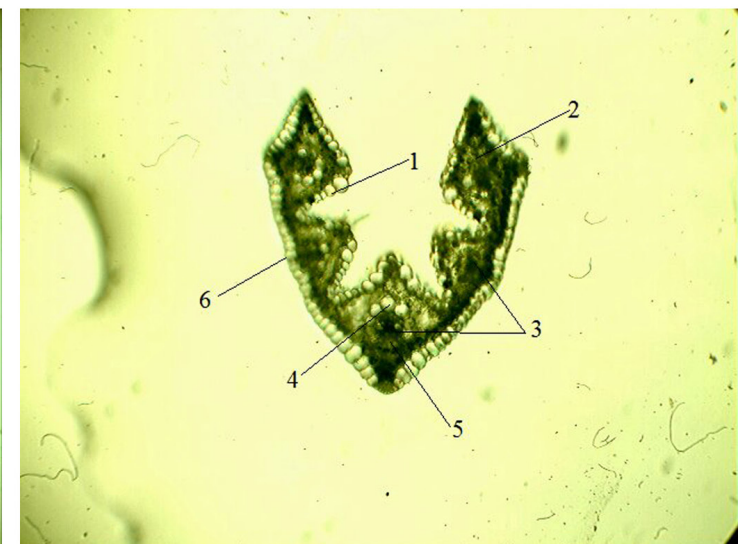

Figure 5. Anatomical structure of the wheatgrass leaf (1 - lower epidermis, 2 - spongy mesophyll, 3 - conductive beam, 4 - lining of the beam, 5 - sclerenchyma of the beam, 6 - upper epidermis)

consisted of three layers: the felloma, fellogen and felloderm. Under the protective tissue, there were parenchymal cells of the primary cortex. The innermost layer of cells in the primary cortex was represented by endoderm cells, which surrounded the central cylinder in a continuous layer. In the central cylinder, sclerenchyma cells were found in groups. The greatest number of them was observed in the plants from the contaminated site. At the very center of the root, there were elements of the xylem and phloem (Fig. 6).

\section{Anatomical structure of the stems of wormwood (Artemisia terrae-albae)}

The stem was covered with 2-3 layers of the epidermis, under which the primary cortex was located. The outer surface of the epidermal cells was thickened due to a thick layer of the cuticle.
This was most pronounced in the plants grown on the heptyl contaminated soil. Under the epidermis, the mechanical tissue was clearly visible: the sclerenchyma and sections of the parenchymal cells arranged in several layers. Conductive beams were arranged in a circle. The conductive beams were collateral, open (between the phloem and xylem was a continuous layer of cambial cells). The number of xylem vessels was increased and they were much smaller in the plants grown on the contaminated soil. In the plants from the control site, the number of xylem vessels was less and they were arranged in a more ordered manner. On top of the phloem was a sclerenchyma lining, consisting of bast fibers. In the very center of the stem, the core parenchyma was located, which had a looser structure and consisted of rounded cells; in the plants from the contaminated area the core cells were smaller, densely closed, with inclusions in the center (Figs. 7 and 8).

\section{Control}

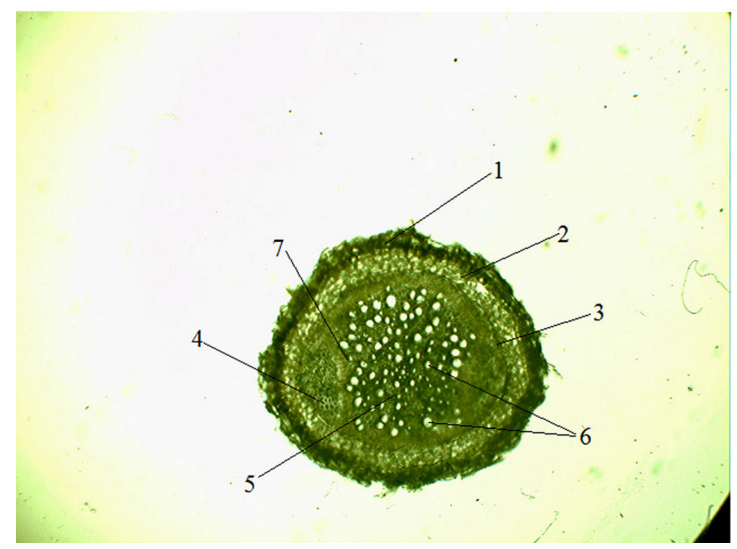

Samples from contaminated soil

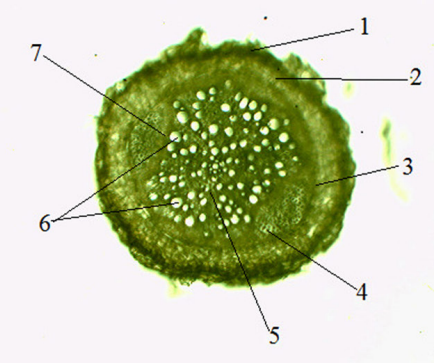

Figure 6. Anatomical structure of the wormwood root (1 - periderm, 2 - parenchymal cells of the primary cortex, 3 - endoderm, 4 - sclerenchyma, 5 - central cylinder, 6 - xylem vessels, 7 - secondary phloem) 


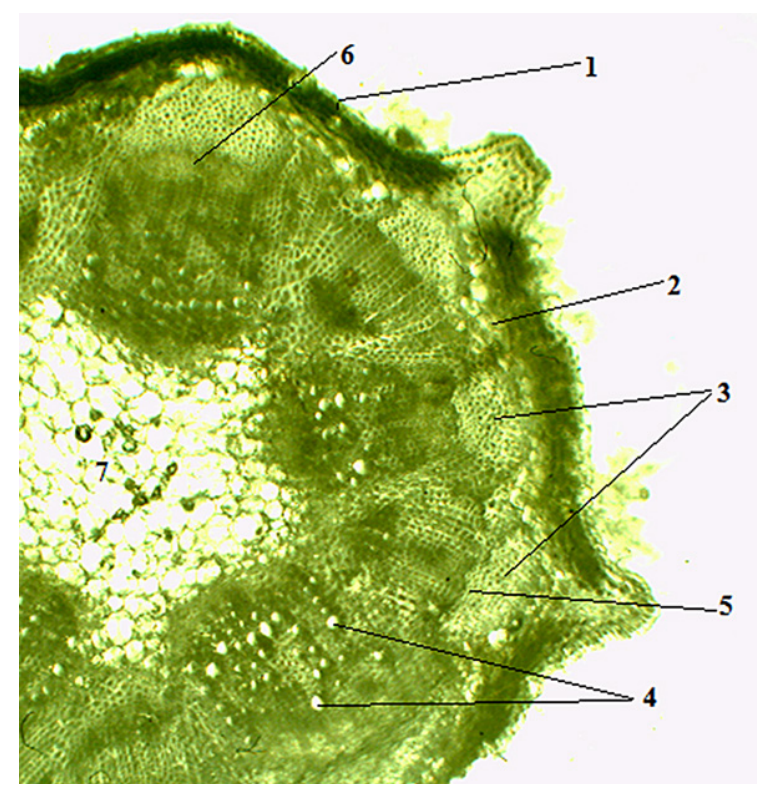

Figure 7. Anatomical structure of the stem of Artemisia terrae-albae (control) $(\times 63)$

( 1 - epidermis, 2 - primary cortex, 3 - sclerenchyma, 4 -xylem, 5 - cambium, 6 - phloem, 7 - core)

\section{Anatomical structure of the leaf blades of wormwood (Artemisia terrae-albae)}

On the outside, the leaf of wormwood was covered with the epidermis. The cells of the upper and lower epidermis were tightly closed. Outside,

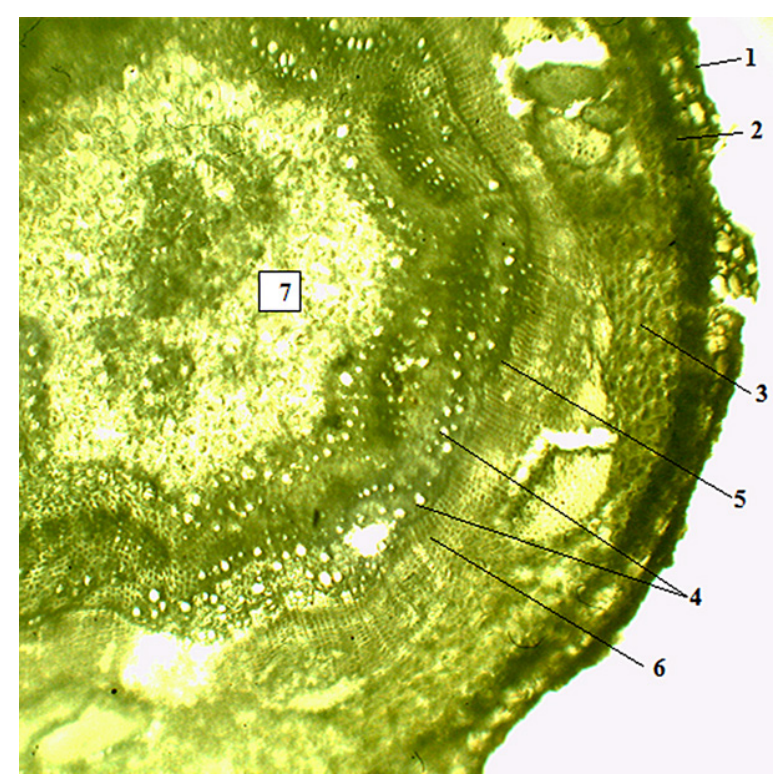

Figure 8. Anatomical structure of the stem of Artemisia terrae-albae (contaminated area) $(\times 63)$ ( 1 - epidermis, 2 - primary cortex, 3 - sclerenchyma, 4 -xylem, 5 - cambium, 6 - phloem, 7 - core)

epidermal cells had a pronounced cuticle, especially in the case of the second sample. Epidermal formations (simple hairs) were visible on the epidermis. The cells of the spongy mesophyll occupied the entire space between the upper and lower epidermis. The mesophyll was homogeneous, loosely

\section{Control}

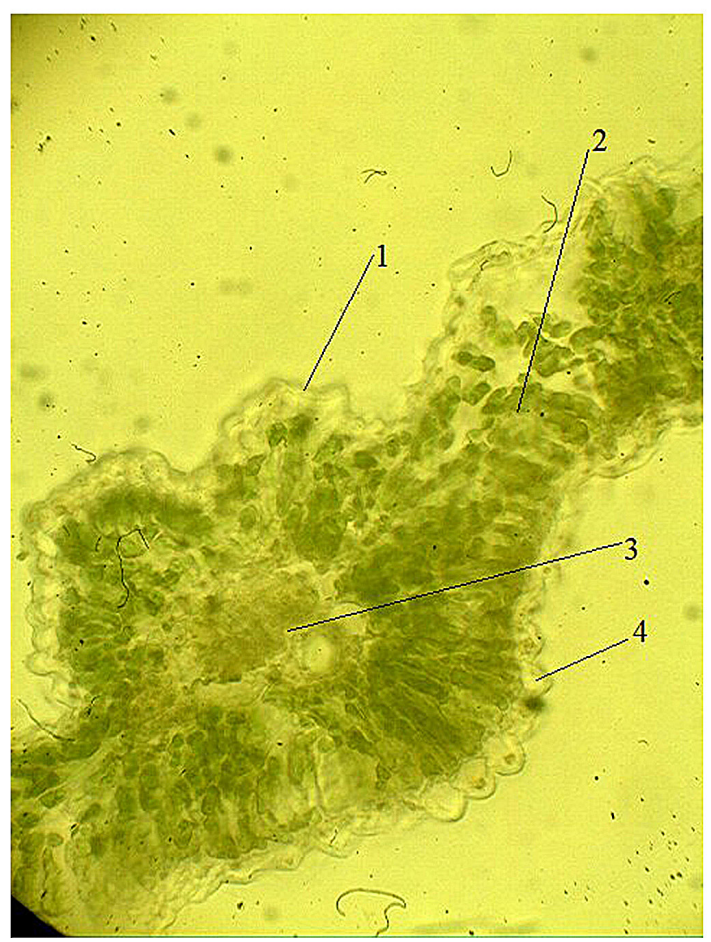

\section{Samples from contaminated soil}

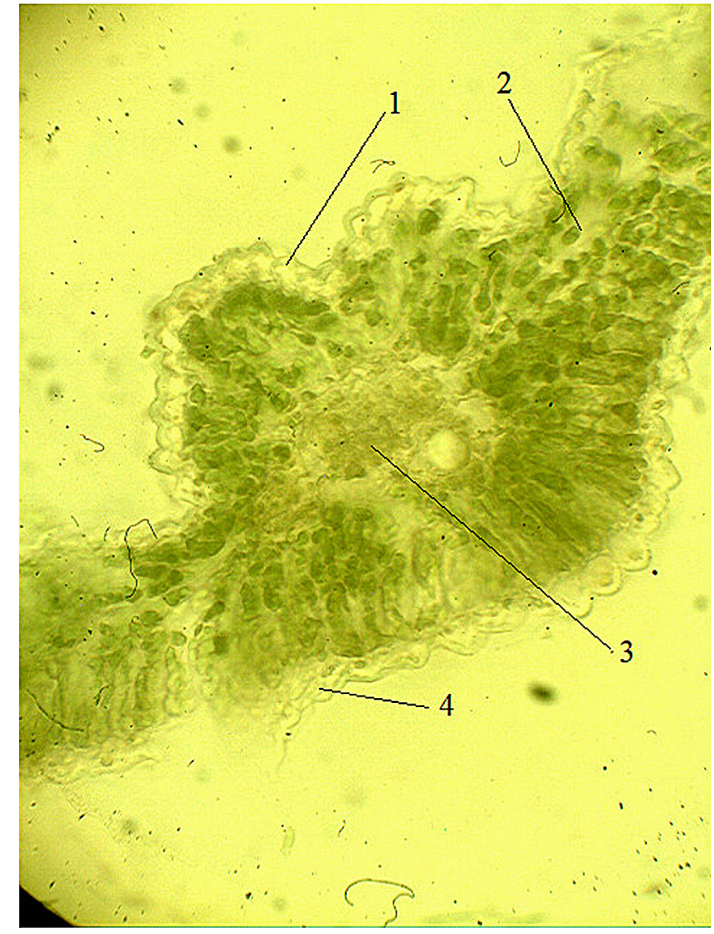

Figure 9. Anatomical structure of the wormwood leaf blade 
Table 1. Biometric indicators of the anatomical structure of leaf blades of the plant species studied

\begin{tabular}{|c|c|c|c|c|c|c|}
\hline \multirow{2}{*}{ Sample } & \multirow{2}{*}{$\begin{array}{c}\text { Soil } \\
\text { contamination } \\
\text { by UDMH and } \\
\text { NDMA, mg/kg }\end{array}$} & \multicolumn{2}{|c|}{$\begin{array}{c}\text { Epidermis } \\
\text { thickness, } \mu \mathrm{m}\end{array}$} & \multirow{2}{*}{$\begin{array}{l}\text { Thickness of the } \\
\text { leaf blade, } \mu \mathrm{m}\end{array}$} & \multirow{2}{*}{$\begin{array}{c}\text { Mesophyll } \\
\text { thickness, } \mu \mathrm{m}\end{array}$} & \multirow{2}{*}{$\begin{array}{c}\text { Area of the } \\
\text { cross-sections of } \\
\text { conductive beams, } \\
\times 10^{-3} \mathrm{~mm}^{2}\end{array}$} \\
\hline & & $\begin{array}{l}\text { of the } \\
\text { upper }\end{array}$ & lower & & & \\
\hline $\begin{array}{l}\text { Bluegrass leaf } \\
\text { (control) }\end{array}$ & & $\begin{array}{l}0.067 \\
0.050 \\
0.075 \\
0.080 \\
0.060 \\
\end{array}$ & $\begin{array}{l}0.060 \\
0.055 \\
0.064 \\
0.085 \\
0.070 \\
\end{array}$ & 0.826 & 0.599 & $\begin{array}{l}0.366 \\
0.359 \\
0.330 \\
0.290 \\
0.298\end{array}$ \\
\hline Mean value & & 0.066 & 0.067 & & & 0.329 \\
\hline $\begin{array}{l}\text { Bluegrass leaf } \\
\text { (contaminated) }\end{array}$ & & $\begin{array}{l}0.080 \\
0.075 \\
0.055 \\
0.060 \\
0.090\end{array}$ & $\begin{array}{l}0.090 \\
0.060 \\
0.080 \\
0.055 \\
0.083\end{array}$ & 0.812 & 0.585 & $\begin{array}{l}0.355 \\
0.340 \\
0.298 \\
0.290 \\
0.289\end{array}$ \\
\hline Mean value & $\begin{array}{c}\text { NDMA } \\
286.99 \\
(28699 \text { MAC) }\end{array}$ & 0.072 & 0.074 & & & 0.314 \\
\hline $\begin{array}{l}\text { Wheatgrass } \\
\text { leaf (control) }\end{array}$ & & $\begin{array}{l}0.055 \\
0.075 \\
0.085 \\
0.064 \\
0.070\end{array}$ & $\begin{array}{l}0.068 \\
0.090 \\
0.080 \\
0.060 \\
0.085\end{array}$ & 1.512 & 0.854 & $\begin{array}{l}0.360 \\
0.288 \\
0.275 \\
0.266 \\
0.270\end{array}$ \\
\hline Mean value & & 0.070 & 0.080 & & & 0.292 \\
\hline $\begin{array}{l}\text { Wheatgrass } \\
\text { leaf } \\
\text { (contaminated) }\end{array}$ & & $\begin{array}{l}0.080 \\
0.070 \\
0.068 \\
0.060 \\
0.055\end{array}$ & $\begin{array}{l}0.085 \\
0.080 \\
0.070 \\
0.062 \\
0.058\end{array}$ & 1.510 & 0.852 & $\begin{array}{l}0.357 \\
0.250 \\
0.255 \\
0.246 \\
0.240\end{array}$ \\
\hline Mean value & $\begin{array}{c}\text { UDMH } \\
39.14 \\
\text { (391.4 MAC) } \\
\end{array}$ & 0.067 & 0.071 & & & 0.270 \\
\hline $\begin{array}{l}\text { Wormwood leaf } \\
\text { (control) }\end{array}$ & & $\begin{array}{l}0.043 \\
0.045 \\
0.034 \\
0.025 \\
0.022 \\
\end{array}$ & $\begin{array}{l}0.046 \\
0.042 \\
0.030 \\
0.035 \\
0.027 \\
\end{array}$ & 1.668 & 1.019 & $\begin{array}{l}0.321 \\
0.365 \\
0.318 \\
0.300 \\
0.295 \\
\end{array}$ \\
\hline Mean value & & 0.034 & 0.036 & & & 0.320 \\
\hline $\begin{array}{l}\text { Wormwood leaf } \\
\text { (contaminated) }\end{array}$ & & $\begin{array}{l}0.030 \\
0.022 \\
0.019 \\
0.015 \\
0.025\end{array}$ & $\begin{array}{l}0.035 \\
0.025 \\
0.030 \\
0.041 \\
0.032\end{array}$ & 1.342 & 0.995 & $\begin{array}{l}0.209 \\
0.275 \\
0.267 \\
0.270 \\
0.230\end{array}$ \\
\hline Mean value & $\begin{array}{c}\text { UDMH } \\
31.32 \\
\text { (313.24 MAC) }\end{array}$ & 0.022 & 0.033 & & & 0.250 \\
\hline
\end{tabular}

arranged. The cells of the columnar mesophyll were elongated perpendicular to the surface of the leaf. In the middle of the leaf, there was a large conductive beam, and at the leaf margins were smaller beams. The conductive tissue consisted of the phloem and xylem, and was combined into closed collateral beams. The large conductive beam was surrounded by sclerenchyma cells, and the smaller beams were immersed in the leaf mesophyll (Fig. 9).

For the best visualization of the results of the comparative analysis, biometric measurements of the anatomical structure of leaf blades, stems and roots of the species studied were carried out. When studying the anatomical structure of a stem of Artemisia terrae-albae grown on contaminated soil, the changes in the internal structure of plants were detected. In the plants from the contaminated area, an increase in quantitative indicators in the stem tissues was observed, i.e. an increase in the size of conductive beams, the thickness of the epidermis, the size of the primary cortex and central cylinder. The data are presented in Tables 1-4.

\section{CONCLUSIONS}

The effect of UD contamination on the growth rate of perennial wild plants was studied. 
Table 2. Biometric indicators of the anatomical structure of roots of the plant species studied

\begin{tabular}{|c|c|c|c|c|c|}
\hline \multirow[b]{2}{*}{ Sample } & \multicolumn{2}{|c|}{ Cortex thickness } & \multirow{2}{*}{$\begin{array}{l}\text { Diameter of the } \\
\text { central cylinder, } \mu \mathrm{m}\end{array}$} & \multirow{2}{*}{$\begin{array}{c}\text { Area of the cross- } \\
\text { sections of xylem } \\
\text { vessels, } \\
\times 10^{-3} \mathrm{~mm}^{2}\end{array}$} & \multirow{2}{*}{$\begin{array}{l}\text { Endoderm } \\
\text { thickness, } \mu \mathrm{m}\end{array}$} \\
\hline & $\begin{array}{l}\text { Exoderm } \\
\text { thickness, } \mu \mathrm{m}\end{array}$ & $\begin{array}{l}\text { Thickness of the } \\
\text { primary cortex, } \mu \mathrm{m}\end{array}$ & & & \\
\hline $\begin{array}{l}\text { Bluegrass } \\
\text { root (control) }\end{array}$ & $\begin{array}{l}0.064 \\
0.075 \\
0.070 \\
0.083 \\
0.060\end{array}$ & $\begin{array}{l}1.037 \\
1.020 \\
1.015 \\
1.031 \\
1.010\end{array}$ & 4.148 & $\begin{array}{l}0.065 \\
0.050 \\
0.045 \\
0.032 \\
0.023\end{array}$ & $\begin{array}{l}0.090 \\
0.081 \\
0.070 \\
0.060 \\
0.063\end{array}$ \\
\hline Mean value & 0.070 & 1.023 & & 0.043 & 0.073 \\
\hline $\begin{array}{l}\text { Bluegrass } \\
\text { root (contaminated) }\end{array}$ & $\begin{array}{l}0.075 \\
0.060 \\
0.051 \\
0.043 \\
0.030\end{array}$ & $\begin{array}{l}0.999 \\
0.893 \\
0.875 \\
0.900 \\
1.009\end{array}$ & 4.135 & $\begin{array}{l}0.060 \\
0.049 \\
0.032 \\
0.025 \\
0.020\end{array}$ & $\begin{array}{l}0.085 \\
0.072 \\
0.063 \\
0.050 \\
0.045\end{array}$ \\
\hline Mean value & 0.052 & 0.935 & & 0.037 & 0.063 \\
\hline $\begin{array}{l}\text { Wheatgrass } \\
\text { root (control) }\end{array}$ & $\begin{array}{l}0.075 \\
0.065 \\
0.060 \\
0.055 \\
0.040\end{array}$ & $\begin{array}{l}0.682 \\
0.628 \\
0.507 \\
0.452 \\
0.460\end{array}$ & 3.655 & $\begin{array}{l}0.017 \\
0.015 \\
0.010 \\
0.008 \\
0.006\end{array}$ & $\begin{array}{l}0.050 \\
0.040 \\
0.032 \\
0.025 \\
0.015\end{array}$ \\
\hline Mean value & 0.059 & 0.546 & & 0.011 & 0.032 \\
\hline $\begin{array}{l}\text { Wheatgrass } \\
\text { root (contaminated) }\end{array}$ & $\begin{array}{l}0.070 \\
0.061 \\
0.055 \\
0.047 \\
0.035\end{array}$ & $\begin{array}{l}0.300 \\
0.343 \\
0.502 \\
0.448 \\
0.440\end{array}$ & 2.780 & $\begin{array}{l}0.007 \\
0.008 \\
0.010 \\
0.006 \\
0.009\end{array}$ & $\begin{array}{l}0.065 \\
0.050 \\
0.049 \\
0.039 \\
0.028\end{array}$ \\
\hline Mean value & 0.054 & 0.407 & & 0.008 & 0.046 \\
\hline $\begin{array}{l}\text { Wormwood root } \\
\text { (control) }\end{array}$ & $\begin{array}{l}0.046 \\
0.042 \\
0.035 \\
0.020 \\
0.015\end{array}$ & $\begin{array}{l}0.628 \\
0.508 \\
0.452 \\
0.600 \\
0.680\end{array}$ & 4.731 & $\begin{array}{l}0.008 \\
0.006 \\
0.009 \\
0.007 \\
0.005\end{array}$ & $\begin{array}{l}0.040 \\
0.032 \\
0.025 \\
0.018 \\
0.013\end{array}$ \\
\hline Mean value & 0.032 & 0.574 & & 0.007 & 0.026 \\
\hline
\end{tabular}

Table 3. Biometric indicators of the anatomical structure of the bluegrass stalk

\begin{tabular}{|l|c|c|c|}
\hline \multicolumn{1}{|c|}{ Sample } & $\begin{array}{c}\text { Thickness of the epidermis, } \\
\mu \mathrm{m}\end{array}$ & $\begin{array}{c}\text { Thickness of the primary } \\
\text { cortex, } \mu \mathrm{m}\end{array}$ & $\begin{array}{c}\text { Diameter of the central } \\
\text { cylinder, } \mu \mathrm{m}\end{array}$ \\
\hline & 0.068 & 0.790 & \\
Bluegrass & 0.047 & 0.674 & \multirow{2}{*}{5.179} \\
stem (control) & 0.050 & 0.501 & \\
\hline Mean value & 0.057 & 0.540 & \\
\hline & 0.035 & 0.720 & \\
Bluegrass & 0.051 & 0.645 & \multirow{2}{*}{5,122} \\
stem (contaminated) & 0.046 & 0.624 & \\
\hline Mean value & 0.030 & 0.589 & \\
\hline
\end{tabular}

Table 4. Morphometric characteristics of the stem of Artemisia terrae-albae

\begin{tabular}{|c|c|c|c|c|}
\hline $\begin{array}{c}\text { Concentration of } \\
\text { UDMH in the soil, } \mathrm{mg} \\
/ \mathrm{kg}\end{array}$ & $\begin{array}{c}\text { Epidermal thickness, } \\
\mu \mathrm{m}\end{array}$ & $\begin{array}{c}\text { Thickness of the } \\
\text { sclerenchyma } \\
\text { lining, } \mu \mathrm{m}\end{array}$ & $\begin{array}{c}\text { Area of the cross- } \\
\text { sections of conductive } \\
\text { beams, } \\
\times 10^{-3} \mathrm{~mm}^{2}\end{array}$ & $\begin{array}{c}\text { Area of the cross- } \\
\text { sections of xylem } \\
\text { vessels, } \\
\times 10^{-3} \mathrm{~mm}^{2}\end{array}$ \\
\hline UDMH & $16.94 \pm 0.28$ & $207.13 \pm 5.29$ & $277.51 \pm 1.23$ & $1.87 \pm 0.18$ \\
$(31.32$ & $17.22 \pm 0.89$ & $238.22 \pm 6.02$ & $258.23 \pm 1.11$ & $1.54 \pm 0.23$ \\
\hline Control & $17.02 \pm 0.56$ & $200.47 \pm 4.36$ & $250.03 \pm 1.82$ & $1.64 \pm 0.19$ \\
\hline & $15.51 \pm 0.67$ & $194.31 \pm 3.18$ & $230.14 \pm 8.35$ & $1.12 \pm 0.11$ \\
& $15.65 \pm 0.82$ & $185.66 \pm 3.27$ & $235.49 \pm 8.29$ & $1.20 \pm 0.09$ \\
\hline
\end{tabular}


1. In the plants grown on the soil contaminated with UD, anatomical and morphological changes were observed in the roots and leaves. In wild bluegrass, and increase in the thickness of the primary cortex was observed, while the thickness of the epidermis and the area of conductive bundles were reduced in the control samples.

In wild bluegrass: there was a decrease in the size of the primary cortex; in the stem increased: the thickness of the primary cortex, sclerenchyma lining, and covering tissue, the area of the conductive bundles, the thickness of the sclerenchyma lining and the area of the conductive bundles were slightly reduced.

Wheatgrass had a more pronounced resistance to UD expressed as the thickening of the root, a decrease in the thickness of the primary cortex, the thickness of the central cylinder, and the area of xylem vessels.

In the central cylinder of wormwood, sclerenchyma cells were found in large numbers.

The changes in the morphological structure of plants under the influence of UD (in particular, in the outer tissue that protects the plant organs from drying out, temperature effects, mechanical damage and other adverse factors) can lead to an imbalance in water metabolism and gas exchange, a deterioration in the absorption and release of water, and the cessation of intake from the soil of both beneficial and harmful substances.

On the basis of the results of the anatomical studies, the following conclusions were drawn: under the influence of pollution, structural changes occur in the vegetative organs (roots and leaves) of the plant species studied; in the anatomical structure of the plant species studied, there was a change in the size of the conductive beams, in the thickness of the epidermis, the size of the primary cortex and central cylinder; it was demonstrated that the plants from different families had a different ability to accumulate chemical compounds.

Earlier studies by S.S. Aidosova, A.B. Akhmetova, N.D. Dolgova, and B. Kenesov (2005) demonstrated that the anatomical features of roots (e.g. the size of the covering tissue and primary cortex, the diameter of the central cylinder and the area of the cross sections of conductive beams and xylem vessels) and leaves (e.g. epidermal thickness, thickness of the leaf blade, the area of the cross sections of conductive beams) can be used as indicators of environmental pollution. The plants studied were characterized by a positive anionic biochemical specialization and reacted to the accumulation in their organs of chemical compounds that were mobile under alkaline conditions.

2. The results of the studies of phytotoxicity of soil conducted under laboratory conditions are a model simulating the effect of soil contaminated with UD on perennial wild plants in natural conditions.

The obtained results can be used in such research fields as ecology, soil science, botany, plant physiology, and can be used to screen various plant species for resistance to soil contamination by UD, to select the plant species most sensitive to UD, that is, plant species that can be used as indicators of soil contamination by UD.

\section{REFERENCES}

1. Environmental safety of the Baikonur Cosmodrome. 2011. Ed. Doctor of Technical Sciences, academician of the MANEB [In Russian] Zh. Zhubatov. Almaty, 430.

2. Carlsen L., Kenesova O.A, Batyrbekova S.E. 2007. A preliminary assessment of the potential environmental and human health impact of unsymmetrical dimethylhydrazine as a result of space activities. Chemosphere, 67(6), 1108-1116.

3. Carlsen L., Kenessov B.N., Batyrbekova S.Y., Kolumbaeva S.Z., Shalakhmetova T.M. 2009a. Assessment of the mutagenic effect of 1,1-dimethyl hydrazine. Environmental toxicology and pharmacology, 28(3), 448-452.

4. Kolumbayeva S., Begimbetova D., Shalakhmetova T., Saliev T., Lovinskaya A., Zhunusbekova B. Chromosomal instability in rodents caused by pollution from Baikonur cosmodrome. 2014. Ecotoxicology, 23(7), 1283-1291.

5. Kenessov B., Alimzhanova M., Sailaukhanuly Y., Baimatova N., Abilev M., Batyrbekova S., Carlsen L., Tulegenov A., Nauryzbayev M. 2012. Transformation products of 1,1-dimethylhydrazine and their distribution in soils of fall places of rocket carriers in Central Kazakhstan. Science of the Total Environment, 427-428, 78-85.

6. Carlsen L., Kenessov B.N., Batyrbekova S.Y. 2009b. A QSAR/QSTR study on the human health impact of the rocket fuel 1,1-dimethyl hydrazine and its transformation products. Multicriteria hazard ranking based on partial order methodologies. Environmental toxicology and pharmacology, 27(3), 415-423.

7. Carlsen L., Kenessov B.N., Batyrbekova S.Y. 2008. A QSAR/QSTR study on the environmental health impact by the rocket fuel 1,1-dimethyl hydrazine 
and its transformation products. Environmental Health Insights, 1, 11-20.

8. Kondratiev A.D., Kasimov N.S., Krechetov P.P., Koroleva T.V. et al. 2015. Ecological Safety of Rocket and Space Activities. [in Russian] Ed. N.S. Kasimova. - M: Sputnik, 280.

9. Ushakova V.G., Shpigun O.N., Starygin O.I. 2004. Ekologo-geokhimicheskaya otsenka mest padeniya raket $\mathrm{v}$ aridnykh landshaftakh Tsentral'nogo Kazakhstana. [Features of chemical transformations of UDMH and its behavior in environmental objects], Polzunovsky Vestnik, 4, 177-184. (in Russian)

10. Puzanov A.V., Vorozheikin A.P., Proskuryakov Yu.V. 2007. Ecological and geochemical assessment of rocket fall sites in arid landscapes of Central Kazakhstan [In Russian]. World of Science, Culture, Education, 7 (19), 21-25.

11. Baitulin I.O., Ogar N.P. 2006. Evaluation of the effect of vegetation transformation in the impact zone of the Baikonur Cosmodrome based on field and experimental studies [in Russian] In: Mater. Scientific and Practical. Conf. "The results of the program to assess the impact of launch vehicles from the Baikonur Cosmodrome on the environment and public health", Almaty-Karaganda, 30-40.

12. Nurusheva A.M. 2006. The study of the action of heptyl (1,1-demethylhydrazine) on the plant organism in the experiment [in Russian]. In: Mater. Scientific Practical Conference. "The results of the program to assess the impact of launch vehicles from the Baikonur Cosmodrome on the environment and public health", Almaty, Karaganda, 99-102.

13. Prozina M.L. 1960. Botanical microtechnics [in Russian], 280.

14. Barykina R.P. et al. 2004. Handbook of Botanical Microtechnology. Basics and methods [in Russian]. Publishing House of Moscow State University, 312.

15. State Pharmacopoeia of the USSR [in Russian]. 1987. Moscow, Nauka, 9(1), 340.

16. State Pharmacopoeia of the USSR [in Russian]. 1990. Moscow, Nauka, 9(2), 231. 